\title{
Is longer unemployment rewarded with longer job tenure?
}

\author{
February 28, 2011 \\ Miki Kohara ${ }^{\dagger}$ \\ Osaka School of International Public Policy, Osaka University \\ Masaru Sasaki \\ Institute of Social and Economic Research, Osaka University \\ Tomohiro Machikita \\ Institute of Developing Economies, Inter-disciplinary Studies Center, Japan External Trade \\ Organization
}

\begin{abstract}
:
This paper examines whether or not a prolonged unemployment period can raise the quality of job matching after unemployment. We focus on job tenure as an indicator of a good quality job match after unemployment. We match two sets of Japanese administrative data compiled by the public employment security offices: one includes information about the circumstances of job seekers receiving unemployment insurance, and the other includes information about job seekers applying for jobs. We first show a negative relationship between unemployment duration and the subsequent job duration. Restricting the sample to job seekers who lower their reservation wage in the final 59 days before expiration of unemployment insurance, we secondly show an even greater negative effect of unemployment duration on the following job duration. The importance lies not only in the duration of unemployment. If job seekers keep a high reservation wage because of the benefits of unemployment insurance, and lower it in response to the expiration of insurance, prolonged unemployment will result in short job duration after unemployment.
\end{abstract}

Key Words: job search, quality of job match, unemployment duration, unemployment insurance JEL Classification Number: J64, J65, J68

\footnotetext{
${ }^{\dagger}$ Corresponding author; Osaka School of International Public Policy, Osaka University, 1-31 Machikaneyama, Toyonaka, Osaka, 560-0043, Japan. E-mail: kohara@osipp.osaka-u.ac.jp. We appreciate Ministry of Health, Labour and Welfare for allowing us to use their administrative data, and the Japan Institute for Labour Policy and Training for helping us to utilize them. We also appreciate Munetomo Ando, Yoshio Higuchi, Yasusada Murata, Fumio Ohtake, Katsuya Takii, Seiro Ito, Hitoshi Sato, Kazushi Takahashi, Kazunari Tsukada, the seminar participants at Kansai Rodo Kenkyukai, ARISH-NUPRI (Nihon University) Economic Workshop, and Institute of Economic Development, and the members of Experimental Research on Efficiency of Job-matching, for their helpful comments. Each author receives Grant-in-Aid for scientific research by the Ministry of Education, Culture, Sports, Science and Technology (MEXT) of the Japanese Government, No.20730156, No. 20530196, and No. 21730212, respectively. The first and the third authors receive Grant-in-Aid for Osaka University Global Centers of Excellence Program by MEXT.
} 


\section{Introduction}

Unemployment insurance is often analyzed in terms of its effect on job search behavior during unemployment. Search theory suggests that unemployment insurance can raise the reservation wage of job seekers, lower search efforts, lower the rates of exit out of unemployment, and thus lengthen the unemployment period. Many empirical studies support this discouraging effect of unemployment insurance on job searches. The jump up in employment around the expiration of unemployment insurance and thus prolonged unemployment duration until the expiration date is reported by many researchers, for example, Moffitt (1985), Katz and Meyer (1990), Poterba and Summers (1995), Green and Riddell (1997), Card and Levine (2000) for the U.S. results, and Carling, Holmlund and Vejsiu (2001), Bover, Arellano and Bentolila (2002), Lalive and Zweimüller (2004), Lalive, Van Ours and Zweimüller (2006), Lalive (2007), and Card, Chetty and Weber (2007) for the European results.

A prolonged period of unemployment, however, does not always produce an undesirable

result. Longer periods of unemployment may lead to a better job match. A limited number of studies have been conducted on this topic, as opposed to the abundant literature on the effect that benefits of unemployment insurance lengthen unemployment duration. The present paper examines the effect of long unemployment duration on job match quality using Japanese microdata that contains information from before, during and after the unemployment period.

Among the limited amount of research on job match quality, several papers examine the relationship between unemployment duration and wage after unemployment. Addison, 
McKinley and Blackburn (2000), Gaure, Roed and Westlie (2008), and Ohkusa (2004) suggest there is a higher wage after longer unemployment. In contrast, Classen (1977), Van Ours and Vodopivec (2006), and Card, Chetty and Weber (2007) suggest there is a lower wage after longer unemployment. The empirical results on the effect that longer unemployment has on job match quality in terms of wage are inconsistent.

We focus on another side of job match quality: job stability after unemployment. Focusing on job duration as a measure of job match quality is important in several senses. First, a low wage at the point when the job began, which is used as a measure of job quality in most empirical investigations of job matching, may not always indicate a bad match. Rather than the wage level at the beginning of employment, a wage increase after that may be an important indicator of job match quality, although wage history is seldom traced over time. Secondly, workers may not place a high value on their wage. They consider many aspects in assessing job quality, including work environment, work satisfaction, convenience in daily life and so on. Job stability, in contrast, measures how agreeable matching is between workers and employers, and reflects all of these aspects. Thirdly, despite its importance, job stability after unemployment has not been sufficiently examined empirically.

We will use two sets of administrative data compiled separately by Japanese public employment security offices. One set is used for the administration of unemployment insurance, that is, to record the circumstances of job seekers receiving unemployment insurance. The other set is used for the administration of finding employment, in other words, to store information about job seekers applying for jobs. We need information from both data sets to examine the relationship between job searching and job matching, so 
we combine the two data sets using an identification number related to unemployment insurance.

The use of these data has several advantages. First of all, our data follow up job losers' behaviors before, during, and after unemployment. This makes it possible to examine the effect of unemployment duration on subsequent job duration, and control for many individual characteristics before and after unemployment.

Second, our data contains information related to the intensity of job searching (based on job application). Although the data do not directly examine reservation wage, we can predict changes in reservation wage by a change in the intensity of job searching. Thus, we can control for changes in reservation wage, which is not sufficiently done in most existing empirical literature in spite of its importance in a theoretical sense.

Third, these data are compiled by public employment security offices for administrative purposes. This makes it possible to avoid the problem of sample selection, because respondents are restricted to recipients of unemployment insurance but are not self-selected, unlike in general survey data. Fourth, the data represent all the unemployed who lost their jobs during the same month in the same year throughout the country. This makes it possible to control for conditions in the macro economy when they became unemployed. Fifth, there has been little research examining the relationship between job search and the quality of job matching in Japan, while the prolonged recession and a dramatic increase in unemployment in Japan have garnered attention in many countries.

Our empirical investigations first show that longer unemployment duration decreases job duration after unemployment. We further show that this negative effect becomes greater if we examine the cases where job seekers lowered their reservation wages and changed 
their intensity of job searching (based on job application) in the final 59 days before expiration of unemployment insurance. That is, longer unemployment duration does lower job stability more seriously, if a job seeker once set a high reservation wage and gave it up later when benefits of unemployment insurance came to lapse. If we consider that job duration is one of the indicators of a high quality job match, longer unemployment duration owing to a high reservation wage does not lead to a better job match.

This paper is composed of four main sections. Theoretical background, the empirical model and related existing literature are given in the next section. The administrative data used in our estimations are introduced in Section III. The empirical results and their implications are reported in Section IV. Concluding remarks are given in the final section.

\section{Theoretical Framework and the Empirical Model}

A simple sequential search model incorporating tenure of a job after unemployment shows that longer unemployment duration leads to a higher separation rate and shorter tenure at a job after unemployment (Appendix shows the details). Suppose that workers are either employed or unemployed at any one point in time. All of the unemployed first receive the benefits of unemployment insurance (UI, hereafter). The UI benefits expire and the receivers become unqualified for UI at a Poisson rate $\delta$. That is, the reservation wage differs depending on the duration of unemployment. A recipient of UI benefits accepts a job offer if the offered wage exceeds the reservation wage $w_{\mathrm{R}}^{\mathrm{h}}$ (Type $h$ worker), while an individual who is no longer qualified for UI benefits accepts the offer if the offered wage exceeds the reservation wage $\mathrm{w}_{\mathrm{R}}^{\mathrm{l}}$ (Type $l$ worker). We assume that 
$\mathrm{w}_{\mathrm{R}}^{\mathrm{h}}>\mathrm{w}_{\mathrm{R}}^{\mathrm{l}}$

Once workers start working after unemployment, an exogenous separation shock occurs for both types of workers. The Type $h$ worker, who has found a job before the expiration of UI benefits, does not stop working even if he or she faces an exogenous separation shock, and continue working until an exogenous death shock arrives. This is because the Type $h$ worker started working when his or her reservation wage exceeded the value of unemployment. In other words, the Type $h$ worker would have a higher job matching quality, because he or she was more selective during unemployment: a higher wage was required to accept an offer.

The Type $l$ worker, who has found a job after UI benefits began to expire, separates from the post-unemployment job and becomes unemployed again once eligible for UI benefits if his or her wage is under a certain wage level, $w_{T .}$. This is the turnover wage for the Type $l$ worker, which is affected both by the reservation wage before and after expiration of UI benefits ( $w_{\mathrm{R}}^{\mathrm{h}}$ and $\mathrm{w}_{\mathrm{R}}^{\mathrm{l}}$, respectively). As explained in Appendix, the Type $l$ worker is likely to separate from the post-unemployment job and search for a better job, as $\mathrm{w}_{\mathrm{R}}^{\mathrm{h}}$ increases. As $\mathrm{w}_{\mathrm{R}}^{\mathrm{l}}$ decreases, the unemployed person is less selective in a job search because he or she prefers to be patient with a lower wage for a while, waiting for another chance to be unemployed once eligible for UI benefits (the entitlement effect). Generous UI benefits raising $w_{R}^{h}$ and lowering $w_{R}^{l}$, result in a decrease in the job match quality, and encourage the Type $l$ worker to shorten his or her subsequent job tenure. Moreover, compared to the Type $h$ workers who started working before UI expiration and thus had a shorter unemployment duration, the Type $l$ workers who started working after UI expiration with longer unemployment duration would have shorter job tenure at the 
post-unemployment job.

There are a limited number of empirical studies which examine whether or not longer unemployment duration leads to lower quality job matching. It is hard to obtain information on workers' search behavior during unemployment, as well as their work behavior after unemployment.

Among available studies, Centeno (2004) shows that generous UI benefits lead to longer subsequent job tenure, using data from US job seekers mainly in the 1980s and 1990s. Van Ours and Vodopivec (2006) find that longer unemployment duration has no effect on the probability of finding a permanent job in Slovenia. Card, Chetty and Weber (2007) also find no relationship between long unemployment duration and subsequent job duration in Austria. In contrast, Belzil (2001) shows that in Canada longer unemployment duration reduces post-unemployment job duration because of a lower reservation wage during the search period. Della Vigna and Paserman (2005) and Paserman (2007) show that impatient job seekers decrease their reservation wage a lot once the UI benefits came to expire, which raises the exit rates around the expiration date, and that the subsequent job match quality, which is measured by wage in the studies above, thus would become lower.

Following the existing empirical studies, we will conduct reduced form estimates of the effect of unemployment duration on separation rates in subsequent jobs. We will analyze parametrically the hazard of job separation. We assume a non-constant hazard over time to allow duration dependence created by heterogeneity. By the empirical test shown in the Results section, we assume a log-normal distribution for the hazard rates:

$$
\lambda\left(\mathrm{t}_{\mathrm{i}} \mid \mathrm{x}_{\mathrm{i}}\right)=\frac{f\left(\mathrm{t}_{\mathrm{i}} \mid \mathrm{x}_{\mathrm{i}}\right)}{1-F\left(\mathrm{t}_{\mathrm{i}} \mid \mathrm{x}_{\mathrm{i}}\right)}=\frac{\frac{1}{\mathrm{t} \sigma \sqrt{2 \pi}} \exp \left(-\frac{1}{2}\left(\frac{\ln (\mathrm{t})-\mathrm{x}_{\mathrm{i}} \beta}{\sigma}\right)^{2}\right)}{1-\Phi\left(\frac{\ln (\mathrm{t})-\mathrm{x}_{\mathrm{i}} \beta}{\sigma}\right)},
$$


where $\Phi$ denotes a normal distribution and $\sigma$ is positive. The explanatory variables, $x_{i}$, include individual characteristics and the variables related to job arrival rates and search efforts. The details are explained in Section IV. We maximize the likelihood of $\ln L(\beta)=\sum_{\mathrm{i}=1}^{\mathrm{n}} \mathrm{d}_{\mathrm{i}} \ln f\left(\mathrm{t}_{\mathrm{i}} \mid \mathrm{x}_{\mathrm{i}} ; \beta\right)+\left(1-\mathrm{d}_{\mathrm{i}}\right) \ln \left[\left(1-F\left(\mathrm{t}_{\mathrm{i}} \mid \mathrm{x}_{\mathrm{i}} ; \beta\right)\right.\right.$, where $F$ and $f$ are the cumulative density and its density of job duration, using BHHH algorithms ${ }^{1}$.

The important aspect in our analysis is to capture the change in reservation wages and search behaviors. Unfortunately, our data do not directly ask the change in reservation wages during unemployment periods ${ }^{2}$. Instead, we can observe the dates of job applications. Using job application dates in conjunction with UI expiration dates, we identify "late appliers" who started applying for a job later during the duration of UI benefits.

Note that this identification depends not only on the unemployment periods, but also on the periods remaining until the expiration of UI benefits. The length of unemployment duration may reflect differences in individuals' heterogeneities other than changes in reservation wages. For example, an individual with low ability may have longer

\footnotetext{
${ }^{1}$ We can allow unobserved heterogeneity by setting the hazard function as $\lambda\left(\mathrm{t}_{\mathrm{i}} \mid \mathrm{x}_{\mathrm{i}}\right) \mathrm{u}_{\mathrm{i}}$ instead of $\lambda\left(t_{\mathrm{i}} \mid \mathrm{x}_{\mathrm{i}}\right)$, adding the unobservable multiplicative error term $u_{i}$, and assuming a gamma distribution for $u_{i}$ with expectation of 1 and variance of $\theta$. We conducted the estimate under this setting of unobservable heterogeneity, and confirmed that the variance component $\theta$ is near zero and statistically insignificant, and that the estimates shown later in Section IV have been hardly changed. ${ }^{2}$ Krueger and Mueller (2008) directly measure search intensity by the number of hours devoted to job search per day, and find that it falls as unemployment benefits become more generous, and rises prior to benefit expiration. Unfortunately, our data do not contain any information on specific time devoted to job searching.
} 
unemployment duration and shorter job tenure, and thus we may find a negative relationship between the two lengths. Likewise, those who have high value of working, and/or those who have strong incentive to work may also show a negative relationship between the two lengths. In those cases, it is an individual's heterogeneity, and not a longer unemployment duration caused by exogenous reasons such as UI benefits, that raises the separation rate at a post-unemployment job. The length of time until UI expiration, on the other hand, can explain the effect of the change in reservation wages more directly, because this length of time is linked to the institutional decisions on UI. We compare the results for the entire sample to those restricted to the late appliers, considering that the latter set and kept high reservation wages in the beginning of the search period and lowered them at the end of the search period in response to the expiration of UI.

The effect of unemployment duration on post-unemployment job duration may be different between young and senior job seekers. In order to investigate this age difference, we separate the whole sample into two groups. One group is composed of job seekers between 16 and 44, and the other group is composed of job seekers between 45 and 64 .

\section{The Data}

\section{III-1. Two Administrative Data Sets}

We use two administrative data sets compiled by the Japanese public employment security offices. One is an administrative data set on unemployment insurance (Koyo Hoken Gyomu Tokei), and the other is an administrative data set on job findings (Shokugyo 
Antei Gyomu Tokei). Although these are compiled separately for different administrative purposes, we merged them using the UI identification number.

The sample is composed of the unemployed who lost their jobs in August 2005. They were all eligible for UI, and appeared in person in public employment security offices to apply for UI. Among them, we use the sample that started working after the unemployment period, because our focus is job duration after unemployment. Thus, our sample is composed of individuals who lost their jobs in August 2005, spent at least one day unemployed, qualified for UI, and worked for at least one day upon finding a job.

We remove those who are over 65 years old, seasonal workers (Tanki Tokurei HiHokensha), and day workers (Hiyatoi Rodosha) because their job seeking behaviors and/or the job market conditions for them may be different from the other individuals in the sample. Most part-time workers (those who work fewer than 20 hours per week), the self-employed, and civil servants are also removed, because they are not usually covered by the UI system. The workers in fixed-term employment after unemployment are also removed because some of them choose short-term employment as an appropriate job for them.

The timing of the survey is summarized in Figure 1. One of the most important variables in this paper is unemployment duration, which is shown as a black dotted line in the figure. This is defined as the period from the day of stopping the previous job until the day prior to starting the subsequent job. During unemployment, job seekers go to a public employment security office to find a job. At the office, they can search for openings mainly on computers and/or in written documents. If a job seeker finds a suitable job, he or she goes to a counter to get direct counsel from a counselor. A counselor provides 
detailed information on the job, and provides advice as to whether or not to apply for the job. If the job seeker decides to apply for the job, the counselor introduces him or her to the employer as an applicant. The job seeker, who is now a job applicant, has an interview, and the employer decides to hire him or her. The job applicant has to inform the public employment security office of receiving an acceptance, and starts working shortly after receiving a formal notice of being hired. A rejected job seeker will continue to search for $\mathrm{a} \mathrm{job}^{3}$.

Another important variable in our study is job tenure after unemployment, which is shown as a thick black line in Figure 1. If the worker had already ceased working at the final survey point (July 2005), his or her job tenure is not truncated but completed, and equal to the period from the first day of starting a job until the last working day. Individual 1 in the figure is an example of this. If the worker continued working at the survey point, his or her temporally-measured tenure, which is the period from the first day of starting a job until the survey point, is truncated. Individuals 2 and 3 are examples of this. We analyze a hazard rate of getting out of a job at one time point, $t$ conditional on surviving until $t-1^{4}$.

\footnotetext{
${ }^{3}$ In Japan, job seekers qualified for UI benefits need to come to a public employment security office to seek for job vacancies when they receive UI benefits. However, the unemployed can find job vacancies through other sources such as newspapers and the internet, and make appointments directly with the employer. Our sample does not include them. We cannot conclude that this overestimates or underestimates the negative effect of unemployment duration on post-unemployment job duration. Job seekers who can receive UI may have high potential for work: Japanese workers are not qualified unless they have worked for at least six months. On the other hand, job seekers who come to the employment security office to consult with the officers have low employment potential or low productivity.

${ }^{4}$ If a length of a temporally-measured job duration is regressed on a length of unemployment
} 
As for the explanatory variables, we control for worker characteristics such as age, a dummy variable indicating gender, a dummy variable indicating a married worker, and years of education. For the information on a job before unemployment, we control for the job tenure of the previous job, a dummy variable indicating whether or not the worker quit a job involuntarily, monthly wage when the worker stopped the previous job, and the monthly wage difference before and after unemployment. To control for market labor conditions, we include effective job rates in the local labor market when the worker started a job after unemployment ${ }^{5}$.

After conducting the estimate in the entire sample, we restrict them to late appliers who may have lowered the reservation wage later during a job search. Our data shows when job seekers apply for job openings, and when benefits of UI expire. We identify those who do not apply for a job opening 59 days prior to the UI expiration date as late appliers. They have kept a high reservation wage while receiving UI benefits, and lowered it later in response to the expiration of UI benefits.

The reason for focusing on 59 days is that it can be a threshold to judge the change in reservation wages, since first-applications for a job opening rise between 60 and 89 days duration, the negative correlation between the two durations can be found by definition, because longer unemployment duration means starting a job at a later point in time, and shorter temporally-measured job duration after unemployment. In our sample, about twenty four percent are a completed sample who once started working and went back to an unemployment pool one year later at the final survey point.

${ }^{5}$ As for post-unemployment wage, it is assumed to be exogenous for simplification. As for the possibility of getting job training, it is not included in explanatory variables, but rather assumed to be controlled for by the other explanatory variables. This is the same assumption made in many other recent empirical studies. Our job duration after unemployment is a maximum of one year, so that the effect of accumulation of human capital may be small. 
before the UI expiration date: about $19.4 \%$ of job seekers in our estimated sample applied for a job opening for the first time more than 90 days before the expiration date, $24.6 \%$ did between 60 and 89 days before the expiration date, 15.8\% did between 30 and 59 days before the expiration date, $16.7 \%$ did between 0 and 29 days before or after the expiration date, and $21.1 \%$ did 30 days after the expiration date. Thus, the job seekers that we defined as lowering reservation wages in the later stages of UI benefits are $56 \%$ of the whole sample ${ }^{6}$.

Figure 1 shows the example of timings of applying for job openings for the first time during unemployment (upward arrow), and the timing of expiration of UI benefits (triangle). In this example, Individual 3 is a late applier. Note that our focus is not just on the timing of the first application (the place of the upward arrow during unemployment), but also the distance of the first application from the end of UI benefits (how far the upward arrow is located from the triangle). Individuals 2 and 3 have identical lengths of unemployment and subsequent truncated job tenure, while they are very different in the sense that Individual 3 changed reservation wage in response to the expiration of UI benefits. In order to find the effects of a change in reservation wage, we examine whether the relationship between the length of unemployment and length of subsequent job tenure would remain unchanged even after restricting the sample to late appliers.

\section{III-2. Unemployment and Job Duration in Our Sample}

\footnotetext{
${ }^{6}$ The other thresholds such as 29 days before the UI expiration date, and anytime after the UI expiration date, can also be examined. The problem of focusing on these thresholds is that the estimate sample, and thus the test power, is decreased.
} 
Panel A of Table 1 shows descriptive statistics of the variables used in our estimate for the whole sample. The average age at unemployment is 36 years old, about $51 \%$ are male, and $42 \%$ are married. The average tenure before unemployment is 1586 days (about 52.9 months), and the average monthly wage before unemployment is about 201 thousand yen. These numbers are smaller than the averages in all of Japan (the average tenure is 13.4 years, and the average monthly wage is 372 thousand yen in 2005 , according to the Basic Survey on Wage Structure compiled by the Statistics Bureau of Japan), which is not surprising since our data includes more young, female workers.

The average unemployment duration, which is also the search period, is about 128 days (4 months). More specifically, the job seekers who found jobs during the first 29 days of their job search make up $10.8 \%$, those between 31 and 60 days are $17.6 \%$, those between 61 and 90 days are $14.2 \%$, those between 91 and 150 days are $17.7 \%$, those between 150 and 210 days are $16.6 \%$, those between 180 and 210 days are $8.2 \%$, and those more than 210 days are $23.2 \%$. During unemployment, all the job seekers in our sample were able to get UI benefits. The potential periods of UI benefit depend on age and tenure in the previous job. About $76.7 \%$ receive 90 days, $8.5 \%$ receive 120 days, $3.7 \%$ receive 150 days, $4.2 \%$ receive 180 days, and the remaining $7.0 \%$ receive either $210,240,270$, or 360 days. About $48 \%$ get out of unemployment with at least one day of UI benefits remaining.

The separation rates 6 and 12 months after starting work at a post-unemployment job are $22.4 \%$ and $27.3 \%$, respectively ${ }^{7}$. Figure 2 shows the empirical survivor function,

\footnotetext{
${ }^{7}$ The last survey point is July 13, 2006, which is about one year after the starting date of unemployment (August, 2005). Thus, the maximum (temporary) tenure after unemployment is
} 
$\widehat{\mathrm{S}}(\mathrm{t})=\Pi_{\mathrm{s}<t}(1-\lambda(\mathrm{s}))$, where $\lambda(s)$ is the hazard function. The figures are shown separately by categories of the number of days of unemployment. The longer the unemployment duration, the more workers separate from jobs after unemployment. The two time periods may not be linearly correlated, so we use logarithms of unemployment duration in our estimation.

As mentioned, we focus on the sample who had not applied for job openings until 59 days before UI expiration. Panel B of Table 1 shows descriptive statistics for them. They are often young, female, and unmarried compared to the entire sample. Their previous job tenure before unemployment is shorter, and most of them quit the job voluntarily (only $2 \%$ stop previous jobs involuntarily), suggesting that they are quitting jobs repeatedly. Their monthly wage in the previous job before unemployment is also lower. Their unemployment duration is longer, and their job duration after unemployment is shorter compared to the entire sample. Figure 3 shows job separation rates by job search intensity. Those who started applying for job openings at least 60 days before the expiration date of UI seem to stay longer at their subsequent jobs.

\section{Results}

Before examining the relationship between unemployment duration and subsequent job duration, we determine the specification of a hazard function for job separation. Several statistics such as Akaike's information criterion and plots of residuals suggest a log-normal distribution for the hazard function. The job separation rate in our data increases

343 days. Since about $70 \%$ are truncated, the average job tenure after unemployment is 163.52 days, or 5.45 months, assuming the maximum tenure for the truncated samples is 343 days. 
progressively, and once the rate reaches its highest value, it starts declining gradually.

Table 2 shows the results using the entire sample. The coefficient of unemployment duration has a negative sign and is significant at the $1 \%$ level. The longer unemployment duration becomes, the shorter job duration is after unemployment. That is, assuming that long job duration reflects a high quality job match, a long period of unemployment lowers the quality of the job match.

We obtain similar results for both the group of younger workers aged from 16 to 44 and the group of older workers aged from 45 to 64 . The estimates are larger for the latter group, which means that the negative effect unemployment duration has on subsequent job tenure is stronger for older workers.

As for the other explanatory variables, the time at a job after unemployment becomes shorter as the workers grow older when they are below the age of 44, and longer as the workers grow older when they are above the age of 45 . Note that the individuals in our sample are those who experienced unemployment at least once. The results may suggest that the younger workers who came back to work from unemployment may quit their job sooner than before- job duration for the younger workers becomes shorter when they quit jobs repeatedly. This tendency is not found in older workers, who know that they face lower demand for their labor once they stop working.

Married workers and male workers over 45 years old stay longer at post-unemployment jobs, because they may have dependents. The more educated people may have higher job match quality because of higher productivity, although this effect is not found in the workers over 45 years old. Job matching for senior workers may be influenced by other factors such as job experience rather than education level. Those who worked for a long 
period in their previous job work for a longer period again in the subsequent job. Those who ceased the previous job involuntarily have shorter job duration after unemployment. In other words, job quitters have high job separation rates. The significantly positive sign of the coefficient of effective job rates suggests that good labor market conditions lead to higher quality job matching. Finally, the wage of the current job makes younger workers stay in the job, although wage incentives may not exist for older workers.

How is the change in reservation wages related to the quality of job matching? In order to examine this, we restrict the sample to the late appliers. Table 3 shows the results obtained for those who had not started job seeking until 59 days before UI expiration during their unemployment periods. The coefficients of unemployment duration are negative and significant at the $1 \%$ significance level for both the younger and older samples. The magnitude of the estimates is much larger than in the case of the entire sample unrestricted to late appliers, which is shown in Table 2. That is, job seekers who have started applying for job openings in less than 59 days before UI expiration separate from their subsequent jobs earlier than the others. This is found not only in younger workers, but also in senior workers. The prolonged duration of unemployment harms post-unemployment job stability more seriously if the job seekers have lowered their reservation wage because of UI expiration.

It might be thought that a larger negative relationship between the length of unemployment duration and the length of subsequent job duration for late appliers has arisen not by setting reservation wages higher but for other reasons. For example, a late applier may have low value of working, and thus she has longer unemployment and shorter job duration. However, such an individual characteristic unrelated to UI settings cannot 
explain our results, since our late appliers are those who changed search behaviors in response to UI expiration. As another point, it may be thought that a late applier can always get a better job: the longer the unemployed wait, the better offer they gain. However, a possibility of getting a better job does not have any relation to UI expiration.

In summary, there is a negative relationship between unemployment duration and job duration after unemployment in Japan. Moreover, longer unemployment duration does hurt job stability more seriously if a job seeker kept reservation wages at a high level based on the amount of UI benefits. The important implication of our results is not that a negative relationship between unemployment and post-unemployment job duration exists, but that the situation would be worse if job seekers kept a high reservation wage with the UI benefits. Prolonged unemployment duration will result in shorter job duration after unemployment if job seekers lower their reservation wage in response to the imminent expiration of UI benefits.

\section{Conclusion}

This paper examined whether or not a prolonged unemployment period can raise the quality of job matching after unemployment. We focused on job tenure as an indicator of a good job match after unemployment. We matched two Japanese administrative data sets compiled by public employment security offices using an identification number related to unemployment insurance.

Our empirical investigation first showed a negative relationship between unemployment duration and the subsequent job duration. The paper then showed this negative effect 
could be greater for the job seekers who put a high reservation wage in the beginning of job search and lowered it later in the final 59 days before the expiration of UI. The importance lies not only in the duration of unemployment. Prolonged unemployment duration will not be rewarded with longer job duration after unemployment, especially when job seekers lower their reservation wages later in response to the expiration of UI. If we consider that job duration is one of the indicators of a good quality job match, longer unemployment duration with lower reservation wage does not lead to a better job match.

There had been little research that examined the matching quality and controlled for the change in reservation wage during unemployment. In addition, there had been little research that investigated job match quality focusing on post-unemployment job stability. The number of empirical examinations for Japanese cases had been especially limited. Our results, which are based on the extensive micro data compiled by the Japanese government, and which utilize information regarding the timing of applications for jobs as well as the timing of expiration of unemployment insurance benefits, may prove as valuable evidence concerning the negative effect that long unemployment with a lowered reservation wage has on subsequent job stability. The UI benefits could make the unemployed keep their reservation wage higher, and thus lead to longer unemployment and shorter subsequent job tenure. 


\section{Appendix. Derivation of wage schemes and comparative statics concerning the} effect of UI benefits on unemployment duration and job tenure after unemployment

The value functions of employment $\left(\mathrm{W}_{\mathrm{h}}(\mathrm{w})\right)$ and unemployment $\left(\mathrm{U}_{\mathrm{h}}\right)$ for the Type $h$ worker who is qualified for UI benefits are given by:

$$
\begin{aligned}
& \mathrm{rW}_{\mathrm{h}}(\mathrm{w})=\mathrm{w}-\sigma \mathrm{W}_{\mathrm{h}}(\mathrm{w}), \\
& \mathrm{rU}_{\mathrm{h}}=\mathrm{z}+\alpha \int_{\mathrm{w}_{\mathrm{R}}^{\mathrm{h}}}^{\overline{\mathrm{h}}}\left[\mathrm{W}_{\mathrm{h}}(\mathrm{w})-\mathrm{U}_{\mathrm{h}}\right] \mathrm{dF}(\mathrm{w})+\delta\left(\mathrm{U}_{\mathrm{l}}-\mathrm{U}_{\mathrm{h}}\right)-\sigma \mathrm{U}_{\mathrm{h}},
\end{aligned}
$$

where $r$ is discount rate, $z$ is unemployment benefits, $\sigma$ is death rate, and $\alpha$ is job arrival rate. An offered wage is randomly drawn from the wage distribution $\mathrm{F}(\mathrm{w})$. The Type $h$ worker, who has found a job before the expiration of UI benefits, does not stop working voluntarily since he or she started working when the offered wage exceeded the reservation wage $\left(w_{R}^{\mathrm{h}}\right)$.

For the Type $l$ worker who is no longer qualified for UI benefits, the value function of being employed $\left(\mathrm{W}_{\mathrm{l}}(\mathrm{w})\right)$ is:

$$
\mathrm{rW}_{\mathrm{l}}(\mathrm{w})=\mathrm{w}+\lambda\left[\max \left(\mathrm{W}_{\mathrm{l}}(\mathrm{w}), \mathrm{U}_{\mathrm{h}}\right)-\mathrm{W}_{\mathrm{l}}(\mathrm{w})\right]-\sigma \mathrm{W}_{\mathrm{l}}(\mathrm{w})
$$

where $\lambda$ represents an exogenous separation shock. After an arrival of a separation shock, the type $l$ employed chooses either to remain employed or to quit and become unemployed with eligibility of the provision of unemployment benefits. If eq.(3) is evaluated at the reservation wage for the type $l$ worker $\left(\mathrm{w}_{\mathrm{R}}^{\mathrm{l}}\right)$, it is rewritten as:

$$
\mathrm{rW}_{\mathrm{l}}\left(\mathrm{w}_{\mathrm{R}}^{\mathrm{l}}\right)=\mathrm{w}_{\mathrm{R}}^{\mathrm{l}}+\lambda\left[\mathrm{U}_{\mathrm{h}}-\mathrm{W}_{\mathrm{l}}\left(\mathrm{w}_{\mathrm{R}}^{\mathrm{l}}\right)\right]-\sigma \mathrm{W}_{\mathrm{l}}\left(\mathrm{w}_{\mathrm{R}}^{\mathrm{l}}\right) .
$$

The max operator implies that the value of unemployment with eligibility of the provision of UI benefits is higher than the value for the type $l$ worker of being employed with the reservation wage: $\max \left(\mathrm{W}_{\mathrm{l}}\left(\mathrm{w}_{\mathrm{R}}^{\mathrm{l}}\right), \mathrm{U}_{\mathrm{h}}\right)=\mathrm{U}_{\mathrm{h}}$. It will be checked later. Equations (1)-(4) 
and the reservation wage properties give:

$$
\begin{aligned}
\mathrm{U}_{\mathrm{l}} & =\frac{(\mathrm{r}+\sigma) \mathrm{w}_{\mathrm{R}}^{\mathrm{l}}+\lambda \mathrm{w}_{\mathrm{R}}^{\mathrm{h}}}{(\mathrm{r}+\sigma)(\mathrm{r}+\sigma+\lambda)} \\
\mathrm{w}_{\mathrm{R}}^{\mathrm{h}} & =\left(\frac{\mathrm{r}+\sigma+\lambda}{\mathrm{r}+\sigma+\lambda+\delta}\right)\left[\mathrm{z}+\left(\frac{\alpha}{\mathrm{r}+\sigma}\right) \int_{\mathrm{w}_{\mathrm{R}}^{\mathrm{h}}}^{\overline{\mathrm{w}}}\left(\mathrm{w}-\mathrm{w}_{\mathrm{R}}^{\mathrm{h}}\right) \mathrm{dF}(\mathrm{w})\right]+\frac{\delta \mathrm{w}_{\mathrm{R}}^{\mathrm{l}}}{\mathrm{r}+\sigma+\lambda+\delta} .
\end{aligned}
$$

When a separation shock arrives, the type $l$ worker, who has found a job after the expiration of UI benefits, voluntarily separates from the post-unemployment job and becomes unemployed again with the eligibility of UI benefits if the current wage is under a certain wage level, $\mathrm{W}_{\mathrm{T}}$. This is referred to as the turnover wage at which the Type $l$ worker is indifferent between the states of unemployment and employment: $\mathrm{W}_{\mathrm{l}}\left(\mathrm{w}_{\mathrm{T}}\right)=\mathrm{U}_{\mathrm{h}}$. These conditions with eqs.(1) and (3) and reservation wage properties give:

$$
\mathrm{w}_{\mathrm{T}}=\mathrm{w}_{\mathrm{R}}^{\mathrm{h}}
$$

Thus, we can summarize the two cases where the Type $l$ worker faces as:

(i) When $\mathrm{w}_{\mathrm{R}}^{\mathrm{l}} \leq \mathrm{w}<w_{T}\left(=\mathrm{w}_{\mathrm{R}}^{\mathrm{h}}\right)$ is offered, the capital gain of being employed is given by:

$$
\underline{W_{l}}(w)-U_{l}=\frac{w-w_{R}^{l}}{r+\sigma+\lambda}
$$

This is derived by eq.(3) with $\max \left(\mathrm{W}_{\mathrm{l}}(\mathrm{w}), \mathrm{U}_{\mathrm{h}}\right)=\mathrm{U}_{\mathrm{h}}$, and eq.(4). The Type $l$ worker separates the current job and becomes unemployed when a separation shock arrives.

(ii) When $w \geq w_{T}\left(=w_{R}^{h}\right)$ is offered, the capital gain of being employed is obtained:

$$
\overline{\mathrm{W}_{\mathrm{l}}}(\mathrm{w})-\mathrm{U}_{\mathrm{l}}=\frac{\mathrm{w}-\mathrm{w}_{\mathrm{R}}^{\mathrm{l}}}{\mathrm{r}+\sigma+\lambda}+\frac{\lambda\left(\mathrm{w}-\mathrm{w}_{\mathrm{R}}^{\mathrm{h}}\right)}{(\mathrm{r}+\sigma)(\mathrm{r}+\sigma+\lambda)} .
$$

This is derived by eq.(3) with $\max \left(\mathrm{W}_{\mathrm{l}}(\mathrm{w}), \mathrm{U}_{\mathrm{h}}\right)=\mathrm{W}_{\mathrm{l}}(\mathrm{w})$, and eq.(5). Type $l$ worker remains employed in the current firm even though a separation shock arrives.

We can rewrite the value function of employment for the Type $l$ workers as 


$$
\mathrm{rU}_{\mathrm{l}}=\alpha \int_{\mathrm{w}_{\mathrm{R}}^{\mathrm{l}}}^{\mathrm{w}_{\mathrm{R}}^{\mathrm{h}}}\left[\mathrm{W}_{\mathrm{l}}(\mathrm{w})-\mathrm{U}_{\mathrm{l}}\right] \mathrm{dF}(\mathrm{w})+\alpha \int_{\mathrm{w}_{\mathrm{R}}^{\mathrm{h}}}^{\overline{\mathrm{w}}}\left[\overline{\mathrm{W}_{\mathrm{l}}}(\mathrm{w})-\mathrm{U}_{\mathrm{l}}\right] \mathrm{dF}(\mathrm{w})-\sigma \mathrm{U}_{\mathrm{l}} .
$$

This with the two wage conditions shown in cases (i) and (ii) gives:

$$
(r+\sigma) w_{R}^{l}+\lambda w_{R}^{h}=\alpha \int_{w_{R}^{l}}^{\bar{w}}\left(w-w_{R}^{l}\right) d F(w)+\frac{\alpha \lambda}{r+\sigma} \int_{w_{R}^{h}}^{\bar{w}}\left(w-w_{R}^{h}\right) d F(w) .
$$

Solving the equations (6) and (8), we get

$$
\begin{gathered}
\mathrm{w}_{\mathrm{R}}^{\mathrm{h}}=\left(\frac{\mathrm{r}+\sigma}{\mathrm{r}+\sigma+\delta}\right)\left\{\mathrm{z}+\left[\frac{\alpha}{\mathrm{r}+\sigma+\lambda}+\frac{\alpha \lambda(\mathrm{r}+\sigma+\delta)}{(\mathrm{r}+\sigma)^{2}(\mathrm{r}+\sigma+\lambda)}\right] \int_{\mathrm{w}_{\mathrm{R}}^{\mathrm{h}}}^{\overline{\mathrm{w}}}\left(\mathrm{w}-\mathrm{w}_{\mathrm{R}}^{\mathrm{h}}\right) \mathrm{dF}(\mathrm{w})\right\} \\
+\left(\frac{\delta}{\mathrm{r}+\sigma+\delta}\right)\left(\frac{\alpha}{\mathrm{r}+\sigma+\lambda}\right) \int_{\mathrm{w}_{\mathrm{R}}^{\mathrm{l}}}^{\mathrm{w}}\left(\mathrm{w}-\mathrm{w}_{\mathrm{R}}^{\mathrm{l}}\right) \mathrm{dF}(\mathrm{w}),
\end{gathered}
$$

and

$$
\begin{aligned}
& \mathrm{w}_{\mathrm{R}}^{\mathrm{l}}=\left(\frac{\lambda}{\mathrm{r}+\sigma+\lambda}\right)\left[-\frac{\mathrm{r}+\sigma+\lambda}{\mathrm{r}+\sigma+\delta} \mathrm{z}+\frac{\alpha \delta}{(\mathrm{r}+\sigma)(\mathrm{r}+\sigma+\delta)} \int_{\mathrm{w}_{\mathrm{R}}^{\mathrm{h}}}^{\overline{\mathrm{w}}}\left(\mathrm{w}-\mathrm{w}_{\mathrm{R}}^{\mathrm{h}}\right) \mathrm{dF}(\mathrm{w})\right] \\
& +\left(\frac{\mathrm{r}+\sigma}{\mathrm{r}+\sigma+\lambda}\right)\left[\frac{\alpha(\mathrm{r}+\sigma+\delta+\lambda)}{(\mathrm{r}+\sigma)(\mathrm{r}+\sigma+\delta)}\right] \int_{\mathrm{w}_{\mathrm{R}}^{\mathrm{l}}}^{\overline{\mathrm{w}}}\left(\mathrm{w}-\mathrm{w}_{\mathrm{R}}^{\mathrm{l}}\right) \mathrm{dF}(\mathrm{w}) .
\end{aligned}
$$

A comparison of these wage equations implies $w_{R}^{h}>w_{R}^{l}$. In addition, we obtain:

$$
\mathrm{W}_{\mathrm{l}}\left(\mathrm{w}_{\mathrm{R}}^{\mathrm{l}}\right)=\frac{(\mathrm{r}+\sigma) \mathrm{w}_{\mathrm{R}}^{\mathrm{l}}+\lambda \mathrm{w}_{\mathrm{R}}^{\mathrm{h}}}{(\mathrm{r}+\sigma)(\mathrm{r}+\sigma+\lambda)}<\frac{\mathrm{w}_{\mathrm{R}}^{\mathrm{h}}}{\mathrm{r}+\sigma}=\mathrm{U}_{\mathrm{h}},
$$

which ensures that, as raised in $\operatorname{eq}(3), \max \left(\mathrm{W}_{\mathrm{l}}\left(\mathrm{w}_{\mathrm{R}}^{\mathrm{l}}\right), \mathrm{U}_{\mathrm{h}}\right)=\mathrm{U}_{\mathrm{h}}$.

These wage equations give a comparative statics system such as:

$$
\left[\begin{array}{ll}
A_{11} & A_{12} \\
A_{21} & A_{22}
\end{array}\right]\left[\begin{array}{l}
w_{R}^{h} \\
w_{R}^{l}
\end{array}\right]=\left[\begin{array}{ll}
B_{11} & B_{12} \\
B_{21} & B_{22}
\end{array}\right]\left[\begin{array}{l}
z \\
\delta
\end{array}\right],
$$

where:

$$
\begin{gathered}
\mathrm{A}_{11}=1+\left(\frac{\mathrm{r}+\sigma+\lambda}{\mathrm{r}+\sigma+\delta+\lambda}\right)\left(\frac{\alpha}{\mathrm{r}+\sigma}\right)\left[1-\mathrm{F}\left(\mathrm{w}_{\mathrm{R}}^{\mathrm{h}}\right)\right]>0, \\
\mathrm{~A}_{12}=-\frac{\delta}{\mathrm{r}+\sigma+\delta+\lambda}<0, \\
\mathrm{~A}_{21}=\lambda+\left(\frac{\alpha \lambda}{\mathrm{r}+\sigma}\right)\left[1-\mathrm{F}\left(\mathrm{w}_{\mathrm{R}}^{\mathrm{h}}\right)\right]>0, \\
\mathrm{~A}_{22}=(\mathrm{r}+\sigma)+\alpha\left[1-\mathrm{F}\left(\mathrm{w}_{\mathrm{R}}^{\mathrm{l}}\right)\right]>0,
\end{gathered}
$$




$$
\begin{gathered}
\mathrm{B}_{11}=\frac{\mathrm{r}+\sigma+\lambda}{\mathrm{r}+\sigma+\delta+\lambda}>0, \\
\mathrm{~B}_{12}=-\frac{\mathrm{r}+\sigma+\lambda}{(\mathrm{r}+\sigma+\delta+\lambda)^{2}}\left[\mathrm{z}+\left(\frac{\alpha}{\mathrm{r}+\sigma}\right) \int_{\mathrm{w}_{\mathrm{R}}^{\mathrm{h}}}^{\overline{\mathrm{w}}}\left(\mathrm{w}-\mathrm{w}_{\mathrm{R}}^{\mathrm{h}}\right) \mathrm{dF}(\mathrm{w})-\mathrm{w}_{\mathrm{R}}^{\mathrm{l}}\right]<0 .
\end{gathered}
$$

The last inequality holds since $z+\left(\frac{\alpha}{r+\sigma}\right) \int_{w_{R}^{h}}^{\bar{w}}\left(w-w_{R}^{h}\right) d F(w)$ shows the reservation wage for UI-qualified unemployed people, which is $w_{R}^{h}$ at $\delta=0$. This should be higher than $\mathrm{w}_{\mathrm{R}}^{\mathrm{l}}$. In addition,

$$
\begin{aligned}
& \mathrm{B}_{21}=0, \\
& \mathrm{~B}_{22}=0 .
\end{aligned}
$$

The Jacobian determinant is $\nabla \equiv \mathrm{A}_{11} \mathrm{~A}_{22}-\mathrm{A}_{12} \mathrm{~A}_{21}>0$. Thus,

$$
\frac{d w_{R}^{h}}{d z}>0, \frac{d w_{R}^{l}}{d z}<0, \frac{d w_{R}^{h}}{d \delta}<0, \frac{d w_{R}^{l}}{d \delta}>0 .
$$

Generous UI benefits either in terms of the amount of benefits (higher $z$ ) or in terms of the length of eligibility (lower $\delta$ ) has a positive effect on $w_{R}{ }^{h}$ but a negative effect on $w_{R}{ }^{l}$.

Finally, the average tenure at the post-unemployment job is

$$
\begin{gathered}
\operatorname{tenure}(\mathrm{h})=\frac{1}{\sigma} \\
\operatorname{tenure}(\mathrm{l})=\left[\frac{\mathrm{F}\left(\mathrm{w}_{\mathrm{R}}^{\mathrm{h}}\right)-\mathrm{F}\left(\mathrm{w}_{\mathrm{R}}^{\mathrm{l}}\right)}{1-\mathrm{F}\left(\mathrm{w}_{\mathrm{R}}^{\mathrm{l}}\right)}\right]\left(\frac{1}{\sigma+\lambda}\right)+\left[\frac{1-\mathrm{F}\left(\mathrm{w}_{\mathrm{R}}^{\mathrm{h}}\right)}{1-\mathrm{F}\left(\mathrm{w}_{\mathrm{R}}^{\mathrm{l}}\right)}\right]\left(\frac{1}{\sigma}\right) .
\end{gathered}
$$

respectively for the Type $h$ worker, and for the Type $l$ worker. In sum, generous UI benefits, changing both reservation wages of $\mathrm{w}_{\mathrm{R}}^{\mathrm{h}}\left(=\mathrm{w}_{\mathrm{T}}\right)$ and $\mathrm{w}_{\mathrm{R}}^{\mathrm{l}}$, lead to a shorter tenure for the workers who found a job after UI expiration. Those who had a longer unemployment period until UI expiration face a higher retention rate and thus shorter tenure at the post-unemployment job compared to those who had a shorter unemployment period. 


\section{References}

Addison, J.T., and Blackburn, M.L. (2000), "The effects of unemployment insurance on postunemployment earnings," Labour Economics, 7, pp.21-53.

Belzil, C. (2001), "Unemployment insurance and subsequent job duration: Job matching versus unobserved heterogeneity," Journal of Applied Econometrics, 16, pp.619-636.

Bover, O., Arellano, M., and Bentolila, S. (2002), "Unemployment duration, benefit duration and the business cycle," Economic Journal, 112, pp.223-265.

Card, D., Chetty, R., and Weber, A. (2007a), "Cash-on-hand and competing models of intertemporal behavior: New evidence from the labor market," Quarterly Journal of Economics, 122. pp.1511-1560.

Card, D., Chetty, R., and Weber, A. (2007b), "The spike at benefit exhaustion: Leaving the unemployment system or starting a new job?” American Economic Review, 97, pp.113-118.

Card, D, and Levine, P.B. (2000), "Extended benefits and the duration of UI spells: Evidence from the New Jersey extended benefit program," Journal of Public Economics, 78, pp.107-138.

Carling, K., Holumlund, B., and Vejsiu, A. (2001), "Do benefit cuts boost job finding? Swedish evidence from the 1990s," Economic Journal, 111, pp.766-790.

Centeno, M. (2004), "The match quality gains from unemployment insurance," The Journal of Human Resources, 39, pp.839-863.

Classen, K.P. (1977), "The effect of unemployment insurance on the duration of unemployment and subsequent earnings," Industrial and Labor Relations Review, 30, pp.438-44.

DellaVigna, S., and Paserman, M.D. (2005), "Job search and impatience," Journal of Labor Economics, 23, pp.527-588.

Gaure, S., Røed, K., and Westlie, L. (2008), "The Impacts of Labor Market Policies on Job Search Behavior and Post-Unemployment Job Quality," IZA Discussion Paper, No.3802.

Green, D.A., and Riddell, W.C. (1997), “Qualifying for unemployment insurance: An empirical analysis," Economic Journal, 107, pp.67-84.

Katz, L.F., and Meyer, B.D. (1990), "The impact of the potential duration of unemployment benefits on the duration of unemployment," Journal of Public Economics, 41, pp.45-72.

Krueger, A.B., and Mueller, A. (2008), "Job Search and Unemployment Insurance: New Evidence from Time Use Data," IZA Discussion Paper, No.3667. 
Lalive, R. (2007), "How do extended benefits affect unemployment duration? A regression discontinuity approach," Journal of Econometrics, 142, pp.785-806.

Lalive, R., Van Ours, J.C, and Zweimüller, J. (2006), "How changes in financial incentives affect the duration of unemployment?" Review of Economic Studies, 73, pp.1009-38.

Lalive, R., and Zweimüller, J. (2004), "Benefit entitlement and unemployment duration: The role of policy endogeneity," Journal of Public Economics, 88, pp.2587-2616.

Moffitt, R. (1985), "Unemployment insurance and the distribution of unemployment spells," Journal of Econometrics, 28, pp.85-101

Ohkusa, Y. (2004), "Programme evaluation of unemployment benefits in Japan: An average treatment effect approach," Japan and the World Economy, 16, pp.95-111.

Paserman, M.D. (2008), "Job Search and Hyperbolic Discounting: Structural Estimation and Policy Evaluation," Economic Journal, 118, pp.1418-1452.

Poterba, J.M., and Summers, L.H. (1995), "Unemployment benefits and labor market transitions: A multinomial logit model with errors in classification," Review of Economics and Statistics, 77, pp.207-216.

Van Ours, J.C, and Vodopivec, M. (2006), "How shortening the potential duration of unemployment benefits affects the duration of unemployment: Evidence from a natural experiment," Journal of Labor Economics, 24, pp.351-378. 


\section{Figure 1. Timing of the Data}

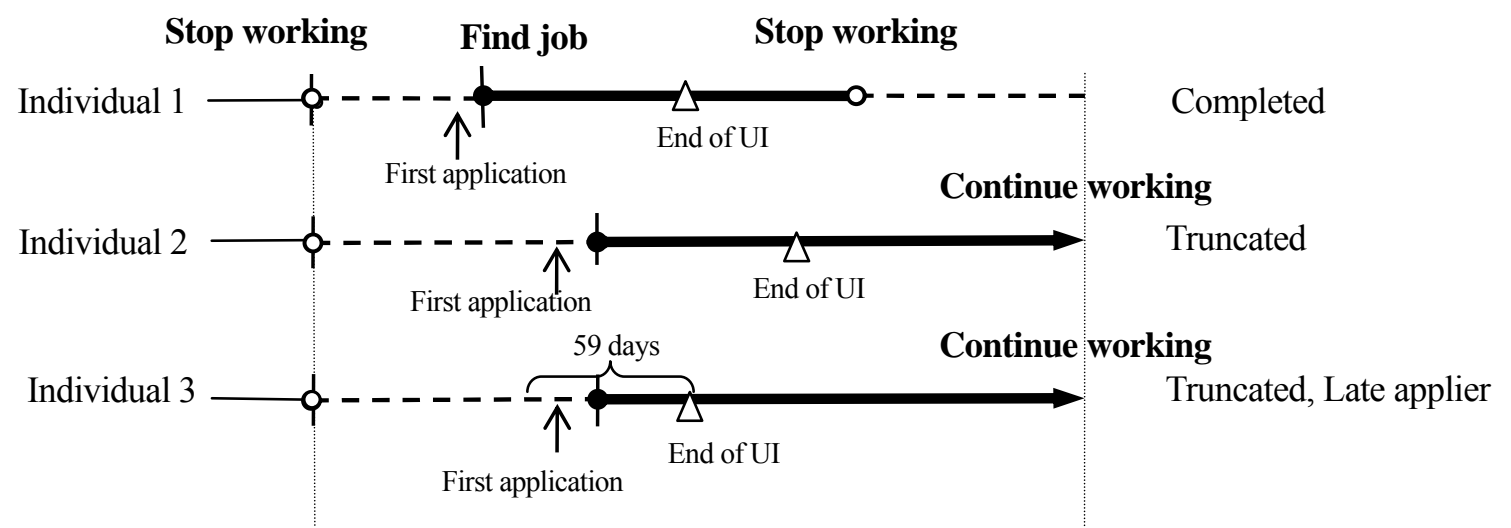

$\underline{\text { August, } 2005}$

$\underline{\text { July, } 2006}$

o----- - Unemployment Duration

Job Tenure 
Figure 2. Post-unemployment job stability by length of unemployment duration

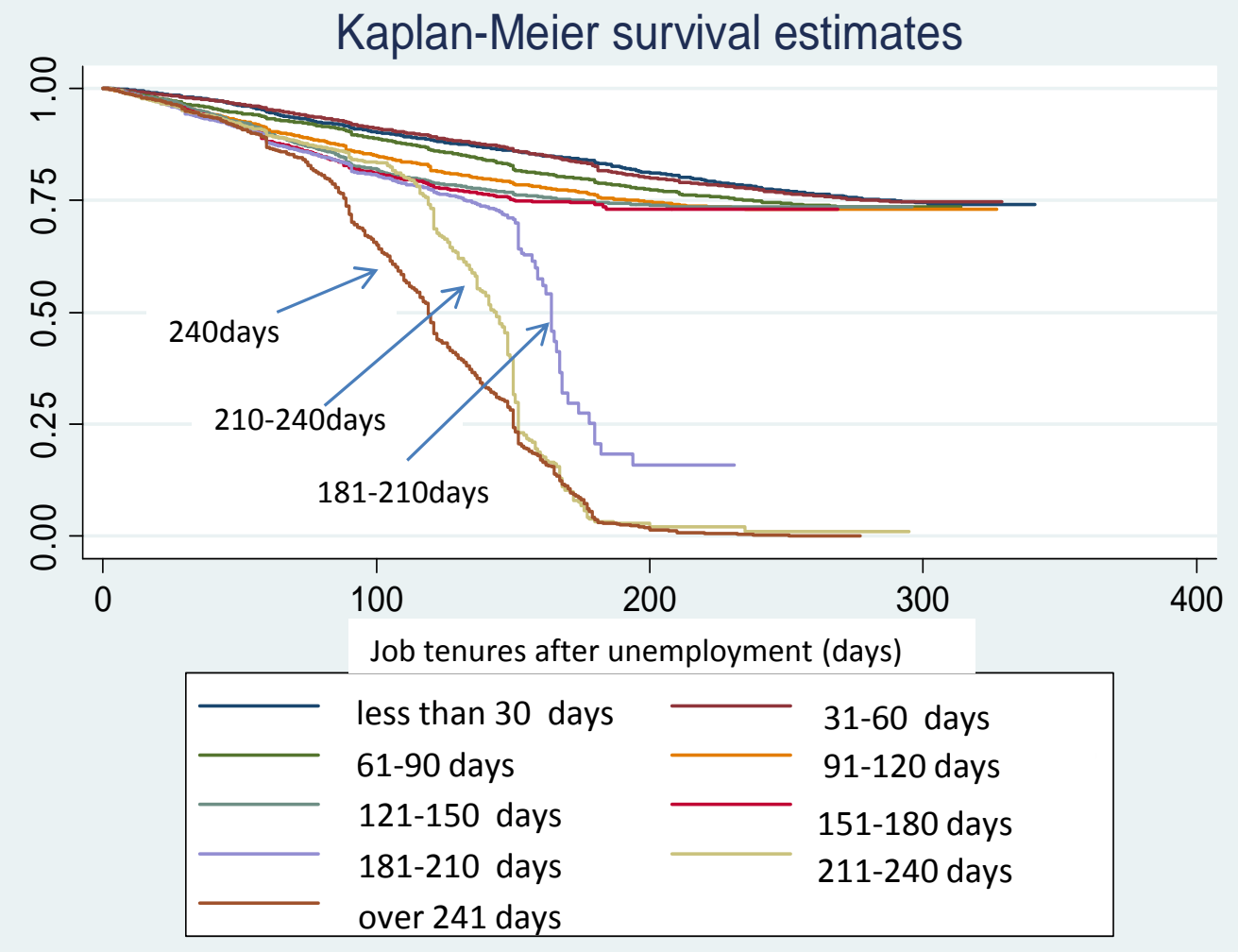

Figure 3. Post-unemployment job stability by job application during unemployment

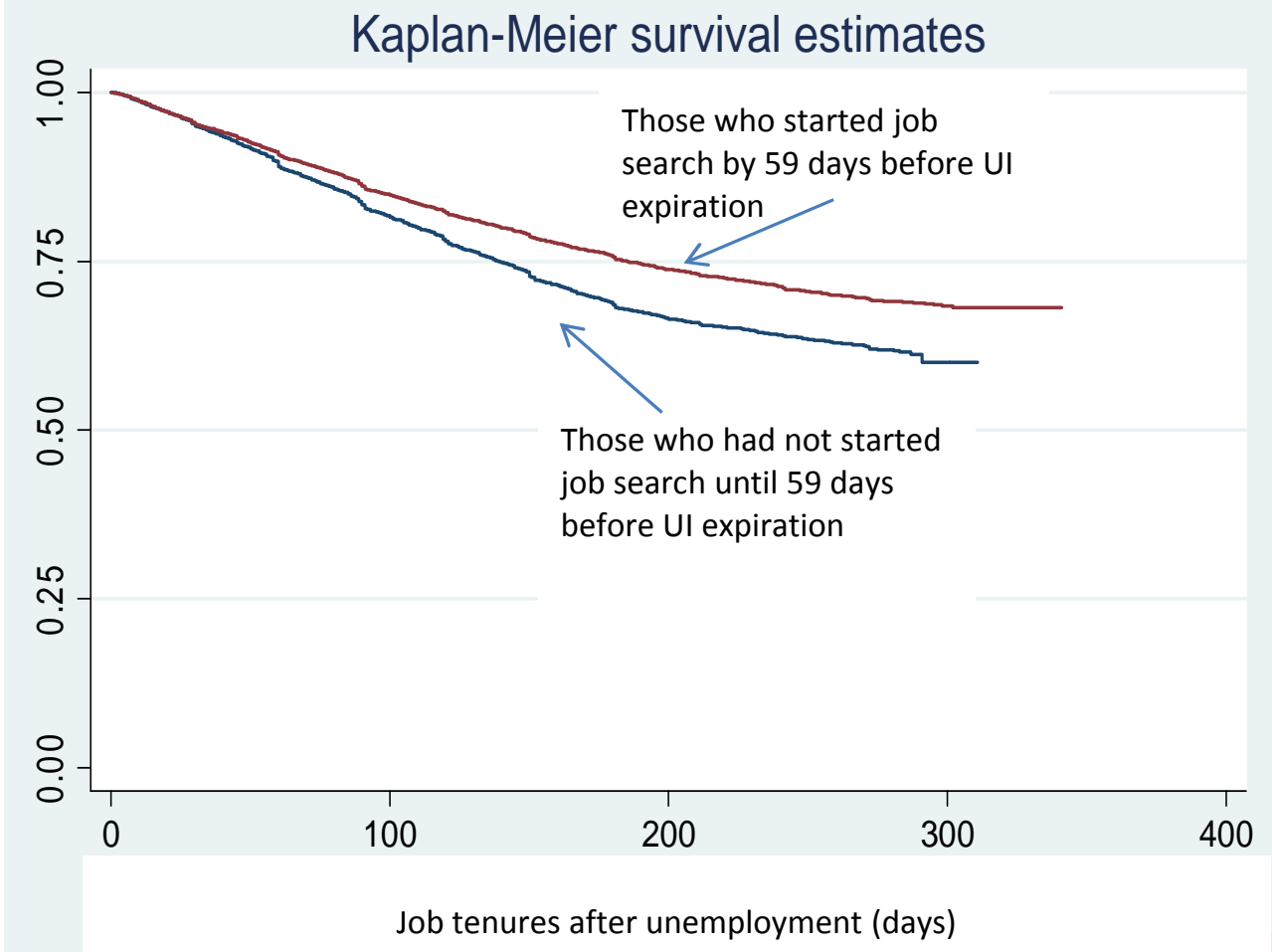




\begin{tabular}{|c|c|c|c|c|c|c|c|c|}
\hline & Mean & $\begin{array}{r}\text { Standard } \\
\text { deviation }\end{array}$ & Minimum & Maximum & Mean & $\begin{array}{l}\text { Standard } \\
\text { deviation }\end{array}$ & Minimum & Maximum \\
\hline job tenures after unemployment & 163.5199 & 89.1002 & 1 & 343 & 132.6334 & 76.9224 & 1 & 311 \\
\hline (log of days) & 4.4949 & 1.0464 & 0 & 5.8406 & 4.9764 & 0.5664 & 0 & 5.817111 \\
\hline (log of years old) & 3.5514 & 0.3017 & 2.7726 & 4.1744 & 3.5017 & 0.2932 & 2.7726 & 4.1589 \\
\hline a dummy variable of male respondent & 0.5085 & 0.4999 & 0 & 1 & 0.4562 & 0.4981 & 0 & 1 \\
\hline a dummy variable of married respondent & 0.4160 & 0.4929 & 0 & 1 & 0.3536 & 0.4781 & 0 & 1 \\
\hline job tenures before unemployment (days) & 1586.826 & 2067.493 & 1 & 16132 & 1503.6760 & 1703.3840 & 7 & 15152 \\
\hline (log of days) & 6.6014 & 1.3872 & 0 & 9.6886 & 6.8471 & 0.9668 & 1.9459 & 9.6259 \\
\hline $\begin{array}{r}\text { a dummy variable of stopping a job involuntarily } \\
\text { before unemployment }\end{array}$ & 0.1103 & 0.3133 & 0 & 1 & 0.0258 & 0.1584 & 0 & 1 \\
\hline $\begin{array}{r}\text { monthly wage in a job after unemployment } \\
\text { (thousands of yen) }\end{array}$ & 200.527 & 101.4319 & 1 & 8210 & 184.9648 & 66.3315 & 1 & 1400 \\
\hline (log of thousands of yen) & 5.2245 & 0.3896 & 0 & 9.0131 & 5.1593 & 0.3629 & 0 & 7.244227 \\
\hline $\begin{array}{l}\text { monthly wage difference before and after } \\
\text { unemployment (thousands of yen) }\end{array}$ & 5.5419 & 114.1484 & -8015 & 8020 & -0.5295 & 78.2763 & -3050 & 1260 \\
\hline
\end{tabular}

Panel A. The entire sample (for Table 2) Panel B. The sample of late appliers (for Table 3)

* The numbers of the observations are 76,565 and 22,204 respectively in the whole sample (Panel A) and in the restricted sample of late appliers (Panel B). 
Table 2. The effect of unemployment duration on retention rates at post-unemployment job

\begin{tabular}{|c|c|c|c|}
\hline & $\begin{array}{l}\text { The entire age } \\
\text { group }\end{array}$ & (a) Age 16-44 & (b) Age 45-64 \\
\hline log of unemployment duration & $\begin{array}{l}-0.0687^{* * *} \\
(0.0067)\end{array}$ & $\begin{array}{l}-0.0597^{* * *} \\
(0.0079)\end{array}$ & $\begin{array}{l}-0.0902^{* * *} \\
(0.0126)\end{array}$ \\
\hline age (years of old) & $\begin{array}{l}-0.194^{* * *} \\
(0.0272)\end{array}$ & $\begin{array}{l}-0.3749^{* * *} \\
(0.0436)\end{array}$ & $\begin{array}{l}0.8572^{* * *} \\
(0.1596)\end{array}$ \\
\hline a dummy variable of male respondent & $\begin{array}{l}0.0083 \\
(0.0162)\end{array}$ & $\begin{array}{l}-0.0302 \\
(0.0186)\end{array}$ & $\begin{array}{l}0.0939^{* * *} \\
(0.0342)\end{array}$ \\
\hline a dummy variable of married respondent & $\begin{array}{l}0.1199^{* * *} \\
(0.0165)\end{array}$ & $\begin{array}{l}0.1152^{* * *} \\
(0.0195)\end{array}$ & $\begin{array}{l}0.1832^{* * *} \\
(0.0308)\end{array}$ \\
\hline $\begin{array}{l}\text { education years } \\
\text { (log of years) }\end{array}$ & $\begin{array}{l}0.4674^{* * *} \\
(0.0503)\end{array}$ & $\begin{array}{l}0.7382^{* * *} \\
(0.0626)\end{array}$ & $\begin{array}{l}0.0754 \\
(0.0866)\end{array}$ \\
\hline $\begin{array}{l}\text { pre-unemployment job tenures } \\
\text { (log of days) }\end{array}$ & $\begin{array}{l}0.1250^{* * *} \\
(0.0053)\end{array}$ & $\begin{array}{l}0.1211^{* * *} \\
(0.0065)\end{array}$ & $\begin{array}{l}0.1251^{* * *} \\
(0.0093)\end{array}$ \\
\hline $\begin{array}{l}\text { post-unemployment wage } \\
\quad(\log \text { of thousands of yen) }\end{array}$ & $\begin{array}{l}0.0705^{* * *} \\
(0.0227)\end{array}$ & $\begin{array}{l}0.1163^{* * *} \\
(0.0293)\end{array}$ & $\begin{array}{l}0.0408 \\
(0.0379)\end{array}$ \\
\hline $\begin{array}{l}\text { wage difference before and after unemployment } \\
\text { (thousands of yen) }\end{array}$ & $\begin{array}{l}-0.0001 \\
(0.0001)\end{array}$ & $\begin{array}{l}-0.0001 \\
(0.0001)\end{array}$ & $\begin{array}{l}-0.00005 \\
(0.00009)\end{array}$ \\
\hline $\begin{array}{l}\text { a dummy variable of stopping pre-unemployment } \\
\text { job involuntarily }\end{array}$ & $\begin{array}{l}-0.0686^{* * *} \\
(0.0228)\end{array}$ & $\begin{array}{l}-0.0771^{* * *} \\
(0.0266)\end{array}$ & $\begin{array}{l}-0.0998^{* *} \\
(0.0450)\end{array}$ \\
\hline $\begin{array}{l}\text { effective job rates when started } \\
\text { post-unemployment job (log of percentage) }\end{array}$ & $\begin{array}{l}0.2368^{* * *} \\
(0.0248)\end{array}$ & $\begin{array}{l}0.2456^{* * *} \\
(0.0315)\end{array}$ & $\begin{array}{l}0.2242^{* * *} \\
(0.0400)\end{array}$ \\
\hline constant & $\begin{array}{l}4.6841^{* * *} \\
(0.1948)\end{array}$ & $\begin{array}{l}4.3674^{* * *} \\
(0.2446)\end{array}$ & $\begin{array}{l}1.6755^{* * *} \\
(0.7406)\end{array}$ \\
\hline Number of the observations & 76565 & 56984 & 19581 \\
\hline Log likelihood & -62483.12 & -46507.788 & -15892.774 \\
\hline Likelihood ratio test: all the parameters are zero. & $957.71^{* * *}$ & $695.56^{* * *}$ & $427.13^{* * *}$ \\
\hline
\end{tabular}


Table 3. The effect of unemployment duration on retention rates at post-unemployment jol :for the samples who started applying for jobs in the final 59 days before expiration
(a) Age 16-44
(b) Age 45-64

\begin{tabular}{lll}
\hline log of unemployment duration & $-0.4190^{* * *}$ & $-0.2537^{* * *}$ \\
age (years of old) & $(0.0276)$ & $(0.0495)$ \\
& $-0.5451^{* * *}$ & $0.972^{* * *}$ \\
a dummy variable of male respondent & $(0.0817)$ & $(0.3330)$ \\
& $-0.0588^{*}$ & 0.0883 \\
a dummy variable of married respondent & $(0.0337)$ & $(0.0709)$ \\
& $0.0652^{*}$ & $0.1088^{*}$ \\
education years & $(0.0364)$ & $(0.0615)$ \\
$\quad$ (log of years) & $0.7796^{* * *}$ & 0.1731 \\
pre-unemployment job tenures & $(0.1168)$ & $(0.1856)$ \\
$\quad$ (log of days) & $0.0950^{* * *}$ & $0.0642^{* *}$ \\
post-unemployment wage & $(0.0173)$ & $(0.0270)$ \\
$\quad$ (log of thousands of yen) & $-0.1321^{* *}$ & -0.1114 \\
wage difference before and after unemployment & $(0.0570)$ & $(0.0876)$ \\
$\quad$ (thousands of yen) & $(0.0002$ & $-0.0009^{* *}$ \\
a dummy variable of stopping pre-unemployment & 0.0060 & $(0.0004)$ \\
job involuntarily & $(0.0480)$ & -0.0681 \\
effective job rates when started & -0.0344 & $(0.0934)$ \\
post-unemployment job (log of percentage) & $(0.0975)$ & -0.2879 \\
constant & $7.9824^{* * *}$ & $(0.1899)$ \\
\hline Number of the observations & $(0.4784)$ & $2.7881^{*}$ \\
Likelihood ratio test: all the parameters are zero. & $343.61^{* * *}$ & $(1.5537)$ \\
\hline
\end{tabular}

